\title{
Spontaneous Monokine Release by Alveolar Macrophages in Chronic Sarcoidosis
}

\author{
János Strausza , Daniela N. Männel ${ }^{\mathrm{b}}$, Sibylle Pfeifer ${ }^{\mathrm{a}}$, Alexander Borkowski ${ }^{\mathrm{a}}$, Rudolf Ferlinz ${ }^{\mathrm{a}}$, \\ Joachim Müller-Quernheim ${ }^{\text {a }}$ \\ ${ }^{\text {a }}$ Third Department of Internal Medicine, Division of Pulmonology, Johannes Gutenberg University, Mainz, and \\ ${ }^{\mathrm{b}}$ Institute of Immunology and Genetics, German Cancer Research Center, Heidelberg, FRG
}

\begin{abstract}
In pulmonary sarcoidosis an activation of alveolar T lymphocytes and alveolar macrophages (AM) has been demonstrated. There is evidence that in contrast to acute disease a heightened T-cell response cannot be observed in the chronic phase of sarcoidosis. The role of AM in the inflammatory process of chronic sarcoidosis is not yet intensively evaluated. To address this question we measured the release of tumor necrosis factor alpha (TNF $\alpha$ ) and interleukin-1 (IL-1) by AM of 39 patients with chronic sarcoidosis (duration $>4$ years; 30 active, 9 inactive diseases) without therapy and correlated the monokine release with parameters of T-cell alveolitis and the course of the disease. The T4/T8 ratio was higher in the active than in the inactive group without reaching statistical significance. TNF $\alpha$ as well as IL-1 is spontaneously released by AM of the active group $2,099 \pm 518 \mathrm{pg} / \mathrm{ml} \mathrm{TNF} \alpha / 10^{6}$ cells $/ 24 \mathrm{~h}$ and $8 / 13$ (IL-1 ${ }^{+} /$total) respectively. In the inactive group the AM release $375 \pm 246 \mathrm{pg} / \mathrm{ml} \mathrm{TNF} \alpha / 10^{6}$ cells $/ 24 \mathrm{~h}$ which is in the range of the control and 1 out of 5 patients was IL-1-positive. There was no correlation between the monokine release and any parameter of T-cell alveolitis. These data support the hypothesis that the inflammatory process in chronic sarcoidosis is dominated by the activity of AM and that this activity determines the course of the disease.
\end{abstract}

\section{Introduction}

Sarcoidosis is a systemic granulomatous disorder of unknown origin characterized by a T-lymphocyte/ alveolar macrophage (AM) alveolitis, granuloma formation and distortion of the normal architecture of the lower respiratory tract [1-3]. The lung is the most commonly involved organ $[4,5]$, and studies with lung inflammatory cells recovered by bronchoalveolar lavage (BAL) revealed an activation of AM and alveolar T lymphocytes [1-7]. In sarcoidosis both cell types spontaneously release immunoregulatory substances (e.g. interleukin (IL)-1, tumor necrosis factor alpha $(\mathrm{TNF} \alpha)$, interferon (INF)-gamma, IL-2, monocytic chemotactic factor and soluble interleukin-2 receptor (sIL-2R) [6-14]) and express activation markers on their cell surface [15-17]. In most studies the patients are grouped according to those criteria of inflammation resulting in groups of patients with inflammatory active or inactive disease. However, from a clinical point of view there are two different kinds of sarcoidosis with completely different characteristics: acute and chronic disease which is not considered by this way of staging $[18,19]$.

There is a clear association between the activity of the disease and the numbers, types and functions of $T$ lymphocytes that are found in the alveolitis [5, 11, 17 19-21]. AM have not been evaluated as extensively as 
Table 1. Clinical and physiological characteristics of the study population

\begin{tabular}{lll}
\hline & $\begin{array}{l}\text { Active } \\
\text { sarcoidosis }\end{array}$ & $\begin{array}{l}\text { Inactive } \\
\text { sarcoidosis }\end{array}$ \\
\hline $\begin{array}{l}\text { Clinical data } \\
\text { Patients, n }\end{array}$ & \\
Age, years & 30 & 9 \\
Male/female & $44.7 \pm 2.7$ & $44.1 \pm 3.7$ \\
Smoker/nonsmoker & $15 / 15$ & $6 / 3$ \\
& $8 / 30$ & $3 / 9$ \\
Pulmonary function test & & \\
VC & & \\
FEV1 $^{1}$ & $75.5 \pm 3.4$ & $89.8 \pm 7.4$ \\
$\mathrm{R}_{\text {tot }}$ & $96.1 \pm 4.0$ & $79.7 \pm 7.1$ \\
\hline
\end{tabular}

$\mathrm{VC}=$ Vital capacity; FEV1 = forced expiratory volume in $1 \mathrm{~s}$; $\mathrm{R}_{\mathrm{tot}}=$ total pulmonary resistance.

1 Expressed as percent predicted. lung $\mathrm{T}$ cells in terms of the pathogenesis of the disorder. However, it is likely that these cells are an important component of the immunopathogenesis of sarcoidosis, because they comprise the majority of the alveolar inflammatory cells and (b) because they are capable of providing accessory signals required for $\mathrm{T}$ cell activation $[22,23]$.

We performed a simultaneous anaylsis of the activity of AM as well as of alveolar T cells in chronic sarcoidosis. To accomplish this, the capacity of AM to release TNF $\alpha$ and IL-1 was evaluated and the surface expression of activation markers of alveolar $\mathrm{T}$ cells was quantified.

\section{Patients and Methods}

Study Population. The diagnosis of sarcoidosis was established in 39 individuals using defined criteria, including transbronchial biopsy [4]. All patients suffered from chronic disease with persisting or undulating clinical signs of inflammation of a minimal duration of 4 years. None of them was receiving therapy at the time of investigation or within the previous 2 months. For the purpose of this study the patients were grouped as having 'clinically active sarcoidosis' or 'clinically inactive sarcoidosis' based on clinical criteria, i.e. new or progressing pulmonary symptoms - such as cough and dyspnea - radiographic abnormalities, or systemic symptoms. There were 30 patients in the clinically active and 9 in the clinical'y inactive group. The two groups did not differ by age, sex, pul- monary function test or smoking history ( $p>0.2$, for all comparisons) (table 1). Seven patients who were bronchoscopized for diagnostic reasons and were free of interstitial lung disease retrospectively or had benign neoplasia, served as controls.

Preparation of Lung Mononuclear Cells. BAL was performed by flexible fiberoptic bronchoscopy with a total volume of $200 \mathrm{ml}$ of $0.9 \%$ sterile saline in four $50-\mathrm{ml}$ aliquots. The original description [24] was slightly modified. The differential cell counts were performed on Wright's stained cytocentrifuge preparations. For subsequent use, the cells recovered were washed 3 times in RPMI 1640 (Gibco, Wiesbaden, FRG), and were resuspended in tissue culture medium. Pure AM ( $>98 \%$ pure) were prepared by FicollHypaque density gradient centrifugation [25] and subsequent 120 min plastic adherence at $4^{\circ} \mathrm{C}$.

Tissue Culture. The AM were cultured over a period of $24 \mathrm{~h}$ without any additives, or in the presence of either $1 \mu \mathrm{g} / \mathrm{ml}$ lipopolysaccharide (LPS) (Escherichia coli, serotype: 055:B5; Sigma, München, FRG) or $10^{6} \mathrm{M}$ prednisolone (Sigma) or both at a density of $10^{6} \mathrm{cells} / \mathrm{ml}$ in RPMI 1640 supplemented with endotoxin-free $10 \% \mathrm{Nu}$ serum (Flow Laboratories, Meckenheim, FRG), $2 \mathrm{mM}$ glutamine (Gibco), $100 \mathrm{U} / \mathrm{ml}$ penicillin (Gibco) and $100 \mu \mathrm{g} / \mathrm{ml}$ streptomycin (Gibco) 24-well tissue culture plates (Nunc, Wiesbaden, FRG) in $5 \% \mathrm{CO}_{2}$ humidified atmosphere at $37^{\circ} \mathrm{C}$. At the end of the culture period the supernatants were harvested and stored at $-20^{\circ} \mathrm{C}$ until they were tested for TNF $\alpha$ and IL-1 activity.

$T N F \alpha$ Assay. TNF $\alpha$ was determined by an enzyme-linked immunosorbent assay (ELISA) as described [27] with some modifications: Briefly, 96-well flat-bottom plates (Titertek Immuno Assay-Plate, Flow Laboratories) were coated with monoclonal anti-recombinant human TNF $\alpha(\operatorname{rhTNF} \alpha)$ antibody (clone 195; kindly provided by Dr. E. Schlick, Knoll AG, Ludwigshafen, FRG) 5 $\mu \mathrm{g} / \mathrm{ml}$ in $\mathrm{NaHCO}_{3}$ buffer $(0.05 \mathrm{M}, \mathrm{pH} 9.0)$ for $16 \mathrm{~h}$ at $4^{\circ} \mathrm{C}$. Serial dilutions of the test samples in phosphate buffer $(0.1 \mathrm{M}, \mathrm{pH} 7.5$, $2 \%$ EDTA, $1 \%$ bovine serum albumin (BSA)) were applied to the plates for $2 \mathrm{~h}$ at room temperature after the wells had been blocked with $1 \%$ BSA in phosphate-buffered saline (PBS) for $2 \mathrm{~h}$ at room temperature. Plates were washed with PBS containing $0.05 \%$ Tween and $2.7 \mu \mathrm{g} / \mathrm{ml}$ biotin (Sigma)-conjugated affinity purified (Protein A-Diasorb) polyspecific rabbit anti-rhTNF $\alpha$ antibodies were added to the wells for $1.5 \mathrm{~h}$ at room temperature. After extensive washing with PBS containing $0.05 \%$ Tween streptavidin-peroxidase complex (Boehringer Mannheim, FRG) at a dilution of 1:10,000 was applied for $30 \mathrm{~min}$ at room temperature. The plates were washed again and the substrate solution $(10 \mathrm{mg}$ 1,2-phenyldiamine (OPD; Sigma) in $10 \mathrm{ml}$ acetate-citric acid buffer $(0.1 M, \mathrm{pH} 4.9)$ and $\left.20 \mu \mathrm{l} 3 \% \mathrm{H}_{2} \mathrm{O}_{2}\right)$ was added to the complex. The reaction was stopped with $2 \mathrm{M} \mathrm{H}_{2} \mathrm{SO}_{4}$, and absorption was measured at $492 \mathrm{~nm}$. The absorption curves obtained with the test samples were compared with a standard curve obtained with rhTNF $\alpha$ (kindly provided by Dr. E. Schlick, Knoll AG) and the $\mathrm{TNF} \alpha$ content expressed as $\mathrm{pg} / \mathrm{ml}$.

IL-1 Activity. IL-1 activity was determined by the conventional costimulator assay [28]. In brief, single cell suspension of $\mathrm{C} 3 \mathrm{H} /$ HeJ thymocytes $\left(5 \times 10^{5}\right.$ cells/culture) were cultured in the presence of phytohemagglutinin (PHA-M, $5 \mu \mathrm{g} / \mathrm{ml}$, Sigma) and serial dilutions of the test samples for 3 days. The culture was pulsed with $1 \mu \mathrm{Ci}$ tritiated thymidine $\left(\left(6-{ }^{3} \mathrm{H}\right)\right.$ thymidine, specific activity $50 \mathrm{Ci} / \mathrm{mM}$; Amersham Buchler, Braunschweig, FRG) for $6 \mathrm{~h}$ and incorporated counts were determined. IL-1 titers are given as the final dilutions of the supernatants which cause cpm 2.5-fold higher 


\section{A/ spontaneous release}

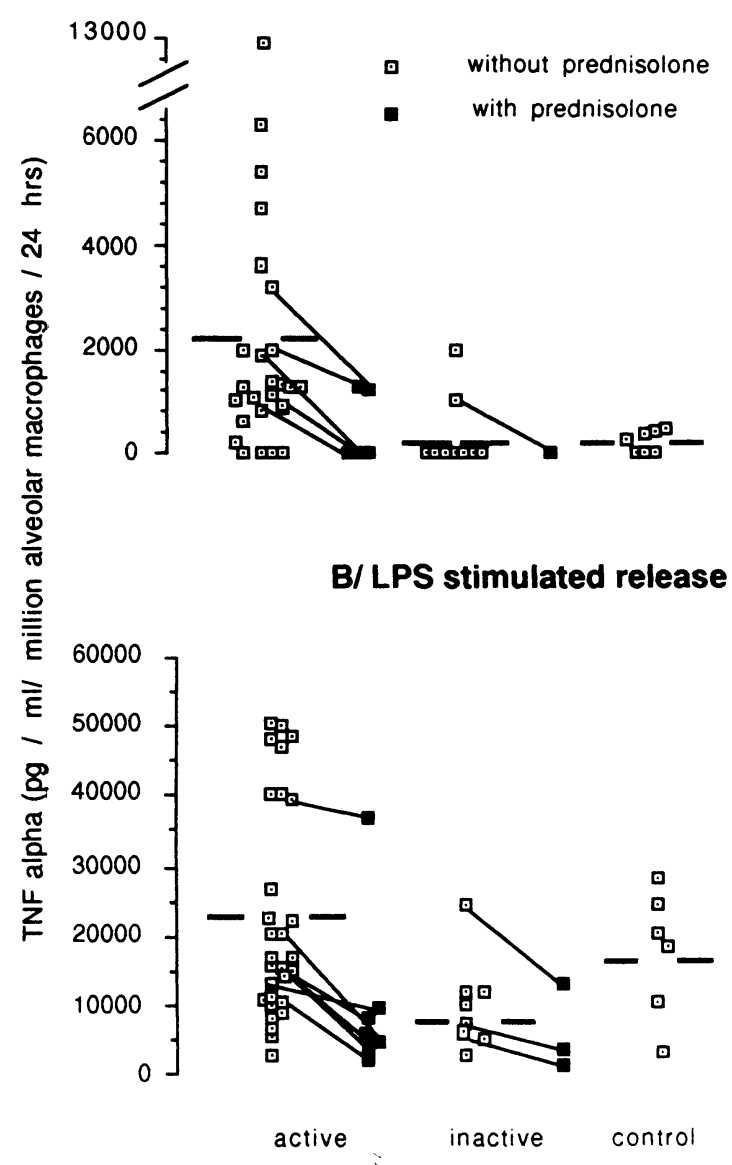

Fig. 1. Spontaneous (A), LPS-stimulated $(1 \mu \mathrm{g} / \mathrm{ml})$ (B) and prednisolone-inhibited $\left(10^{-6} M\right)$ TNF $\alpha$ release by $10^{6} \mathrm{AM}$ of patients with active and inactive chronic sarcoidosis and of the control group. The horizontal bars indicate the mean. than background. Control experiments demonstrated that the addition of the tissue culture aadditives (LPS, prednisolone) in the concentration applied did not influence this assay.

Monoclonal Antibodies and Staining Procedure. Cells were stained with unconjugated monoclonal antibodies directed against CD3, CD4, CD8, HLA-DR (Becton-Dickinson, Heidelberg, FRG), CD25, CD16 (Ortho Diagnostic Systems GmbH, Neckargemünd, FRG), and VLA-1 (T-Cell Sciences, Cambridge, Mass., USA) at a concentration suggested by the suppliers. Cells were fixed on polylysine-coated slides, and developed with an immunoperoxidase technique [29].

Statistical Methods. All comparisons were made by using either the two-tailed Student's $t$ test or the Mann-Whitney $U$ test. The comparisons of the distributions of sex and smoking history of the study population were done by using $\chi^{2}$ test. All data are expressed as mean \pm standard error of the mean (SEM).

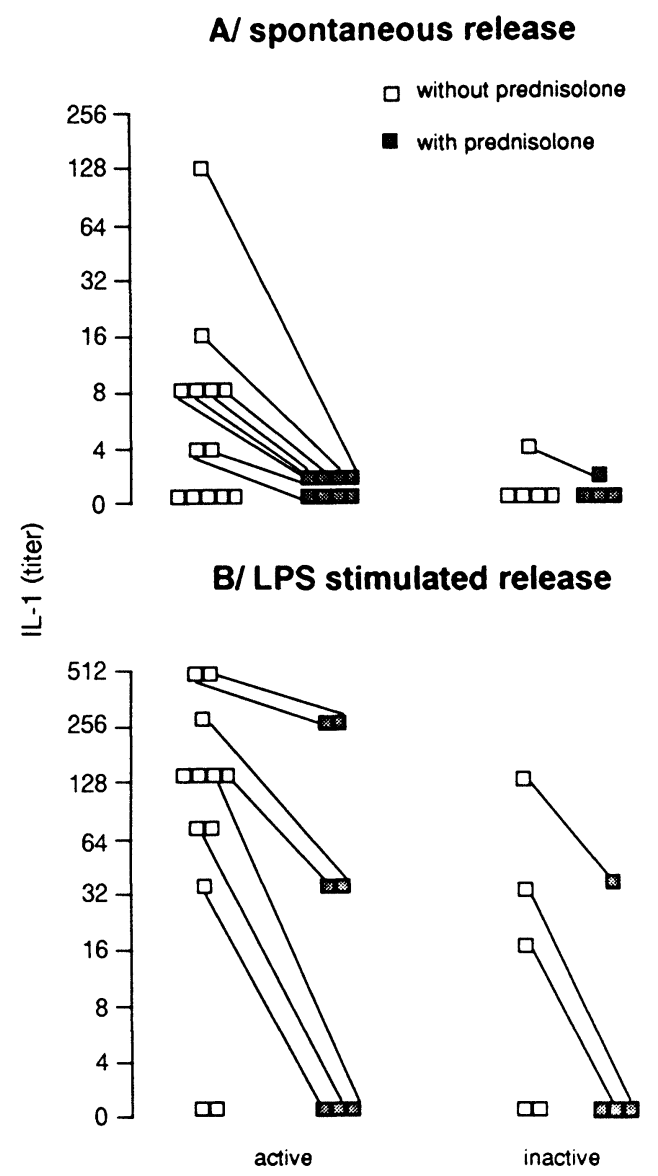

Fig. 2. Spontaneous (A), LPS-stimulated $1 \mu \mathrm{g} / \mathrm{ml}$ (B) and prednisolone-inhibited $\left(10^{-6} M\right)$ IL-1 activity of AM of patients with active and inactive chronic sarcoidosis.

\section{Results}

T-Cell Activation Markers. In BAL of patients with active sarcoidosis a considerable increase of total cells recovered $\left(20.8 \pm 3.9\right.$ vs. $12.7 \pm 3.8 \times 10^{6} / 100 \mathrm{ml}$ recovered BAL) and an increase in the $\mathrm{CD} 4 / \mathrm{CD} 8$ ratio (3.8 vs. 2.7) can be observed. However, there is only a marginal increase in the percentage of BAL lymphocytes in active disease $(21.5 \pm 2.4$ vs. $14.8 \pm 3.3 \%)(p<0.05)$ (table 2). Both groups of patients exhibit a slight elevation in the expression of HLA-DR, IL-2R, CD16, and VLA-1 by BAL lymphocytes without any significant difference between active and inactive disease. 
In relationship to the reported alterations in acute disease the increase of the CD4/CD8 ratio as well as the expression of the activation markers is only moderately elevated.

$T N F \alpha$ Release. AM of patients with active sarcoidosis spontaneously release $\mathrm{TNF} \alpha$ in considerable amounts $(2,099 \pm 518 \mathrm{pg} / \mathrm{ml})$. In marked contrast, AM of patients with inactive sarcoidosis release much lower quantities $(375 \pm 246 \mathrm{pg} / \mathrm{ml})$ which are in the range of the background of the assay and do not differ from control ( $261 \pm 86 \mathrm{pg} / \mathrm{ml} ; \mathrm{p}>0.2)$ (fig. 1A). Concerning the spontaneous $\mathrm{TNF} \alpha$ release, the inactive group and the control differ significantly from active disease ( $p<0.002$ in both comparisons). Stimulation of the AM with LPS results in a heightened monokine production in all three groups $(22,906 \pm 3,011 \mathrm{pg} / \mathrm{ml}$ in active, $9,738 \pm 2,240 \mathrm{pg} / \mathrm{ml}$ in inactive disease, and $17,189 \pm 3,671 \mathrm{pg} / \mathrm{ml}$ in the control group) (fig. 1B). The difference between active and inactive disease is of statistical significance ( $\mathrm{p}<0.05$ ). $10^{-6} \mathrm{M}$ prednisolone notably inhibited the spontaneous $\mathrm{TNF} \alpha$ release (80\% suppression in the active group) (fig. 1A). The LPS-stimulated TNF $\alpha$ release as well is considerably reduced in both groups by the addition of prednisolone (fig. 1B).

IL-1 Release. The results obtained with the IL-1 assay parallel the findings described for TNF $\alpha$. In the active group a substantial spontaneous IL-1 release (62\% of the patients) which is sensitive to prednisolone can be observed (fig. 2). The LPS-stimulated IL-1 release of these AM is markedly reduced by prednisolone resulting in a 2 -fold lower average titer of the positive samples. In the inactive group in 4 out of 5 patients no spontaneous IL-1 release can be found. In only 1 out of 5 patients tested, an activity above the background range of the assay at the lowest possible dilution of 1:4 was observed. In this group as well the LPS-stimulated IL-1 release was inhibitable by prednisolone.

\section{Discussion}

The presented analysis demonstrates (a) that in chronic sarcoidosis the spontaneous monokine release segregates well with the activity of the disease, (b) that this AM activity can be suppressed by in vitro application of corticosteroids, and (c) that signs of T-cell activation do not parallel the functional activity of AM.
Table 2. BAL cells characteristics of patients with active and inactive sarcoidosis

\begin{tabular}{lcc}
\hline & $\begin{array}{l}\text { Active } \\
\text { sarcoidosis }\end{array}$ & $\begin{array}{l}\text { Inactive } \\
\text { sarcoidosis }\end{array}$ \\
\hline Total cells counts $^{1}$ & $20.8 \pm 3.9$ & $12.7 \pm 3.8$ \\
AM, \% & $77.5 \pm 2.4$ & $84.1 \pm 3.5$ \\
Neutrophils, \% & 2 & $<2$ \\
Lymphocytes, \% & $21.5 \pm 2.4^{\mathrm{a}}$ & $14.8 \pm 3.3$ \\
CD3 & $92.1 \pm 1.1^{\mathrm{b}}$ & $83.6 \pm 3.2$ \\
CD4 & $68.5 \pm 3.1^{\mathrm{c}}$ & $54.5 \pm 4.4$ \\
CD8 & $25.2 \pm 3.0$ & $28.8 \pm 4.0$ \\
CD4/CD8 & $3.8 \pm 0.8$ & $2.7 \pm 0.9$ \\
HLA-DR & $15.8 \pm 2.1$ & $12.5 \pm 2.5$ \\
CD25 & $5.5 \pm 0.5$ & $4.8 \pm 1.3$ \\
CD16 & $1.9 \pm 0.6$ & $0.7 \pm 0.2$ \\
VLA-1 & $7.9 \pm 1.4$ & $7.8 \pm 1.6$ \\
\hline
\end{tabular}

${ }^{\mathrm{a}} \mathrm{p}<0.05 ;{ }^{\mathrm{b}} \mathrm{p}<0.005 ;{ }^{\mathrm{c}} \mathrm{p}<0.03$.

$1 \times 10^{6}$ in $100 \mathrm{ml}$ BAL recovered.

Our findings are in conflict - regarding the T-cell segment of the alveolitis - with some previously published reports of exaggerated T-cell activity in sarcoidosis [30-34]. To the best of our knowledge there are no studies available focusing on the alveolitis of the chronic form of the disease. Greenings et al. [35] reported a decrease of BAL lymphocytes in correlation to the duration of the disease and Hollinger et al. [36] demonstrated that patients with inflammatory active sarcoidosis and low numbers of BAL lymphocytes have a high risk of treatment failure and subsequent development of chronic disease. The wide range of alterations in T-cell alveolitis found in the literature may be due to the amalgamation of patients with acute and chronic disease in groups with active and inactive sarcoidosis $[15,16,21,30-33]$.

$\mathrm{AM}$ and monocytes are known to differ in their capacities to release monokines. AM release more TNF $\alpha$ and less IL- 1 than an equal number of monocytes [37]. It is feasible to assume that in sarcoidosis the inflammatory milieu of the lower respiratory tract activates the AM resulting in the release of monokines, TNF $\alpha$ as well as IL- 1 have been reported to be present in the alveolitis of sarcoidosis [7, 8, 38-40]. Here we additionally demonstrate that the spontaneous monokine release segregates with the clinical ac- 
tivity of the disease and that the pathological findings of functional AM activity are dominating the alveolitis of chronic sarcoidosis. The observation of only marginal alterations regarding the T-lymphocytic alveolitis is in accordance with the fact of reduced percentages of BAL lymphocytes in chronic disease.

Using the thymocyte proliferation assay, Hunninghake [7] and ourselves could find sarcoidosis patients with IL-1-positive AM. Employing the same method this could not be found by Kleinhenz et al. [38] and Eden and Turino [39]. On the mRNA level, IL-1- and TNF $\alpha$-positive AM could be found [40]. Recently, Spatafora et al. [41] demonstrated a heightened TNF $\alpha$ release after LPS stimulation of mononuclear cells of patients with active sarcoidosis. Here we confirm and extend this observation. In the active group a heightened LPS-induced and a considerable spontaneous TNF $\alpha$ release could be observed. As reported by Spatafora et al. regarding the stimulated release, the difference between active and inactive disease is of statistical significance. Additionally, we could clear-cut demonstrate a spontaneous TNF $\alpha$ release by AM of the active group. This activity is well beyond the low levels of TNF $\alpha$ release by AM of the inactive and the control group respectively. In contrast to our study, Spatafora et al. used different experimental conditions for AM stimulation and a cytotoxic bioassay for the evaluation of TNF $\alpha$. The experimental differences in combination with different patient populations and control groups might well account for the differences in these observations.

Wewers et al. [42], however, demonstrated IL-1 mRNA-negative AM in a large group of sarcoidosis patients with a highly active alveolitis. Several facts could explain these apparently contradictory results. The thymocyte proliferation assay can easily be hampered by immunosuppressive compounds present in the test samples, e.g. inhibitors binding IL-1 or blocking receptors transducing the mitogenic signals [43, 44]. The activation threshold to release monokines is linked to class II genes [45]. This may result in different IL-1 and IL-1 mRNA levels in study populations of different ethnical composition.

In in vitro experiments TNF $\alpha$ and IL- 1 are usually coexpressed [43], thus the in vivo coexpression at the mRNA as well as the protein level can be expected. The two genes are only transcribed over a short period of time after stimulation followed by a long refractory period. Thus, only few cells in BAL can be expected to transcribe the genes and to release the monokines. In this context the different regulation of the two genes might be of relevance. The predominantly posttranscriptional regulation of IL-1 may result in an immediate decay of the mRNA in the ex vivo situation [46].

Our findings have some implications for the current concept of the immunopathogenesis of sarcoidosis:

(a) Acute and chronic disease differ substantially in the characteristics of their alveolitis with a dominance of $T$ cells in acute and a dominance of AM in chronic disease. Thus, the alveolitis of chronic sarcoidosis is characterized by a moderate increase in the percentage of $T$ cells and an accumulation of functionally activated AM. Consequently, new staging systems should include parameters of AM activity, especially in the evaluation of patients with chronic disease.

(b) TNF $\alpha$ and IL-1 are products of AM which are able to stimulate these macrophages [47-50]. This heightens the possibility of the maintenance of the inflammation of chronic disease by an autocrine stimulation of AM [49]. Such a mechanism of stimulation has been demonstrated in in vitro systems for monocytic cells [48] as well as for T lymphocytes [51].

(c) A monocyte influx to the alveoli and a local proliferation of AM have been observed in sarcoidosis [52]. Besides the known chemoattractants released by sarcoid T cells TNF $\alpha$ is also chemotactic for monocytes from the peripheral blood [50] resulting in an additional mechanism of monocyte accumulation in the alveoli.

(d) IL-2 release is a critical feature of the T-cell alveolitis. Sarcoid AM are known to express the IL-2 receptor and IL-2 is able to stimulate TNF $\alpha$ release by monocytes [53]. Thus the T-cell and the AM segment of the sarcoid alveolitis might influence each other and the T-cell alveolitis might up-regulate the AM activity resulting in chronic disease.

(e) In inactive disease the spontaneous as well as the LPS-stimulated monokine release are markedly lower than in active disease. The high LPS response is a consequence of the long-lasting in vivo preactivation of the AM which is known to induce an exaggerated monokine release by macrophages [38]. It is conceivable that this preactivation is delivered by the unknown etiological agent of sarcoidosis. Activated macrophages release the monokines tested only over a short period of time after stimulation [37]. Consequently, the activation must have taken place in the 
hours preceding the BAL and the stimulating agent has to reside in the alveoli, as it has been suggested for the T-cell activation in the course of sarcoidosis. The decrease in the LPS response as well as the quiescent AM in inactive disease give evidence that the underlying processes maintaining the inflammation are overcome. However, there is still no clear-cut evidence if this stimulating process is based on a nominal antigen or an immunodysregulation. The result of such an immunodysregulation could be the exaggerated accessory activity of sarcoid AM. The observed AM activation is compatible with both possibilities.

(f) The administration of corticosteroids is in general of clinical benefit and limits the inflammatory symptoms of sarcoidosis. This might well be a sequela of its impact on the inflammatory activity of macrophages, because corticosteroids are known to suppress the monokine release and the accessory functions of these cells [54]. The cachectic effect of TNF $\alpha$ which is a possible cause of the clinical symptoms of the disease can be blocked by the administration of corticosteroids [55].

Thus, our observations give further support to the hypothesis of an immunodysregulation as the underlying pathogenetical principle of sarcoidosis.

\section{Acknowledgment}

This study was supported by Naturwissenschaftlich-Medizinisches Forschungszentrum, Mainz, and Federal Ministry of Technology and Research, FRG (No. 01KE8804/0). J.S. was supported by the Humboldt Foundation.

The authors wish to thank M. Hemmerlein for the excellent technical assistance.

\section{References}

1 Crystal, R.; Gadek, J.; Ferrans, V.; Fulmer, J.; Line, B.; Hunninghake, G.: Interstitial lung diseases: Current concept of pathogenesis, staging, and therapy. Am. J. Med. 70: 542-568 (1981).

2 Crystal, R.G.; Bitterman, P.B.; Rennard, S.I.; Keogh, B.A.: Interstitial lung disease of unknown cause: disorders characterized by chronic inflammation of the lower respiratory tract. $\mathrm{N}$. Engl. J. Med. 310: 154-156 (1984).

3 Crystal, R.G.; Bitterman, P.B.; Rennard, S.I.; Keogh, B.A.: Interstitial lung disease of unknown cause: disorders characterized by chronic inflammation of the lower respiratory tract. 2 . N. Engl. J. Med. 310: 235-245 (1984).

4 Thomas, P.D.; Hunninghake, G.W.: Current concepts of pathogenesis of sarcoidosis. Am. Rev. Respir. Dis. 135: 747-760 (1987).
5 Hunninghake, G.W.; Fulmer, J.D.; Young, R.C.; Gadek, J.E.; Crystal, R.G.: Localisation of the immune response in sarcoidosis. Am. Rev. Respir. Dis. 120: 49-57 (1979).

6 Hunninghake, G.W.; Bedell, G.N.; Zavala, D.C.; Monick, M.; Brady, M.: Role of interleukin-2 release by lung $\mathrm{T}$ cells in active pulmonary sarcoidosis. Am. Rev. Respir. Dis. 128: 634 636 (1983).

7 Hunninghake, G.W.: Release of interleukin-1 by alveolar macrophages of patients with active pulmonary sarcoidosis. Am. Rev. Respir. Dis. 129: 569-572 (1984).

8 Bachwich, P.R.; Lynch, J.P.; Larrick, J.W.; Spengler, M.; Kunkel, S.L.: Tumor necrosis factor production by human sarcoid alveolar macrophages. Am. J. Pathol. 125: 421-425 (1986).

9 Nathan, C.F.; Prendergast, T.J.; Wiebe, M.E.; Stanley, E.R.; Platzer, E.; Remold, H.G.; Welte, K.; Rubin, B.Y.; Murray, H.W.: Activation of human macrophages. Comparison of other cytokines with interferon gamma. J. Exp. Med. 160: 600-605 (1984).

10 Nugent, K.M.; Glazier, J.; Monich, M.M.; Hunninghake, G.W.: Stimulated alveolar human macrophages secrete interferon. Am. Rev. Respir. Dis. 131: 714-718 (1985).

11 Müller-Quernheim, J.; Saltini, C.; Sondermeyer, P.; Crystal, R.G.: Compartmentalized activation of the interleukin-2 gene by lung T-lymphocytes in active pulmonary sarcoidosis. J. Immunol. 137: 3475-3483 (1986).

12 Saltini, C.; Spurzem, J.R.; Lee, J.J.; Pinkston, P.; Crystal, R.G.: Spontaneous release of interleukin-2 by lung $\mathrm{T}$-lymphocytes in active pulmonary sarcoidosis is primarily from the Leu3 ${ }^{+} \mathrm{DR}^{+}$ T-cell subset. J. Clin. Invest. 77: 1962-1970 (1986).

13 Robinson, B.W.S.; McLemore, T.; Crystal, R.G.: Gamma interferon is spontaneously released by alveolar macrophages and lung T-lymphocytes in patients with pulmonary sarcoidosis. J. Clin. Invest. 75: 1488-1495 (1985).

14 Lawrence, E.C.; Brousseau, K.P.; Berger, M.B.; Kurman, C.C.; Marcon, L.; Nelson, D.L.: Elevated concentration of soluble interleukin-2 receptors in serum samples and bronchoalveolar fluids in active sarcoidosis. Am. Rev. Respir. Dis. 137: 759-764 (1988).

15 Hancock, W.W.; Kobzik, L.; Colby, A.J.; O’Hara, C.J.; Cooper, A.G.; Godleski, J.J.: Detection of lymphokines and lymphokine receptors in pulmonary sarcoidosis. Am. J. Pathol. 123: 1-8 (1986).

16 Costabel, U.; Bross, K.J.; Rühle, K.H.; Lohr, G.W.; Matthys, H.: Ia-like antigens on T-cells and their subpopulations in pulmonary sarcoidosis and hypersensitivity pneumonitis. Am. Rev. Respir. Dis. 131: 337-342 (1985).

17 Semenzato, G.; Chilosi, M.; Ossi, E.; Trentin, L.; Pizzolo, G.; Cipriani, A.; Agostini, C.; Zambello, R.; Marcer, G.; Gasparotto, G.: Bronchoalveolar lavage and lung histology, comparative analysis of inflammatory and immunocompetent cells in patients with sarcoidosis and hypersensitivity pneumonitis. Am. Rev. Respir. Dis. 132: 400-404 (1985).

18 Cantin, A.; Crystal, R.G.: Interstitial pathology: An overview of the chronic interstitial lung disorders. Int. Archs Allergy appl. Immun. 76: 83-91 (1985).

19 Lin, Y.H.; Haslam, P.L.; Turner-Warwick, M.: Chronic pulmonary sarcoidosis: relationship between lung lavage cell counts, chest radiograph, and results of standard lung function tests. Thorax 40: 501-507 (1985).

20 Kataria, Y.P.; LoBuglio, A.F.; Bromberg, P.A.: Sarcoid lym- 
phocytes: spontaneous transformation and release of macrophage migration inhibition activity. Am. Rev. Respir. Dis. 113: 315-323 (1976).

21 Paradis, I.L.; Dauber, J.H.; Rabin, B.S.: Lymphocytes phenotypes in bronchoalveolar lavage and lung tissue in sarcoidosis and idiopathic pulmonary fibrosis. Am. Rev. Respir. Dis. 133: 855-860 (1986).

22 Ettensohn, D.B.; Lalor, P.A.; Roberts, N.J.: Human alveolar macrophage regulation of lymphocyte proliferation. Am. Rev. Respir. Dis. 133: 1091-1096 (1986).

23 Rich, E.A.; Tweardy, D.J.; Fujiwara, H.; Eller, J.J.: Spectrum of immunoregulatory functions and properties of human alveolar macrophages. Am. Rev. Respir. Dis. 136: 258-265 (1987).

24 Hunninghake, G.W.; Fulmer, J.D.; Young, R.C.; Gadek, J.E.; Crystal, R.G.: Localisation of the immune response in sarcoidosis. Am. Rev. Respir. Dis. 120: 49-57 (1979).

25 Böyum, A.: Isolation of mononuclear cells and granulocytes from human blood. Scand. J. Clin. Invest. 21: suppl., pp. 77-89 (1968).

26 Julius, M.H.; Simpson, E.; Herzenberg, L.A.: A rapid method for the isolation of functional thymus derived murine lymphocytes. Eur. J. Immunol. 3: 645-649 (1973).

27 Kist, A.; Ho, A.D.; Räth, U.; Wiedenmann, B.; Bauer, A.; Schlick, E.; Kirchner, H.; Männel, D.N.: Decrease of natural killer cell activity and monokine production in peripheral blood of patients treated with recombinant tumor necrosis factor. Blood 72: 344-348 (1988).

28 Falk, W.; Krammer, P.H.; Männel, D.N.: A new assay for interleukin-1 in the presence of interleukin-2. J. Immunol. Methods 99: 47-52 (1987).

29 Bross, K.J.; Pangalis, G.A.; Staatz, C.: Demonstration of cell surface antigens and their antibodies by peroxidase-antiperoxidase method. Transplantation 25: 331-334 (1978).

30 Schoenberger, C.I.; Line, B.R.; Keogh, B.A.; Hunninghake, G.W.; Crystal, R.G.: Lung inflammation in sarcoidosis: comparison of serum angiotensin-converting enzyme levels with bronchoalveolar lavage and gallium-67 scanning assessment of T lymphocyte alveolitis. Thorax 37: 19-25 (1982).

31 Baugham, R.P.; Fernandez, M.; Bosken, C.H.; Mantil, J.; Hurtubise, P.: Comparison of gallium-67 scanning, bronchoalveolar lavage and serum angiotensin converting enzyme levels in pulmonary sarcoidosis: predicting response to therapy. Am. Rev. Respir. Dis. 129: 676-681 (1984).

32 Baugham, R.P.; Thorpe, J.E.: Bronchoalveolar lavage can be clinically useful. Chest 90: 791:792 (1986).

33 Chrétien, J.; Venet, A.; Israel-Biet, D.; Sandron, D.; Arnoux, A.: Bronchoalveolar lavage in sarcoidosis. Respiration 48 : 222-230 (1985).

34 Rossi, G.A.: Bronchoalveolar lavage in the investigation of disorders of the lower respiratory tract. Eur. J. Respir. Dis. 69: 293-315 (1986).

35 Greening, A.P.; Nunn, P.; Dobson, N.; Rudolf, M.; Rees, A.D.M.: Pulmonary sarcoidosis: alternations in bronchoalveolar lymphocytes and T cell subsets. Thorax 40: 278-283 (1985).

36 Hollinger, W.M.; Staton, G.W.; Fajman, W.A.; Gilman, M.J.; Pine, J.R.; Check, I.J.: Prediction of therapeutic response in steroid-treated pulmonary sarcoidosis. Am. Rev. Respir. Dis. 132: 65-69 (1985).

37 Martinet, Y.; Yamagauchi, K.; Crystal, R.G.: Differential expression of tumor necrosis factor/cachectin gene by blood and lung monoculear phagocytes. Am. Rev. Respir. Dis. 138: 659665 (1988)

38 Kleinhenz, M.E.; Fujiwara, H.; Rich, E.A.: Interleukin-1 production by blood monocytes and bronchoalveolar cells in sarcoidosis. Ann. N.Y. Acad. Sci. 465: 91-97 (1986)

39 Eden, E.; Turino, G.M.: Interleukin-1 secretion by human alveolar macrophages stimulated with endotoxin is augmented by recombinant immune (gamma) interferon. Am. Rev. Respir. Dis. 133: 455-460 (1986).

40 de Rochemonteix, B.; Junod, A.; Dayer, J.: Expression of mRNA of interleukin- $1 \alpha, \beta$ and tumor necrosis factor $\alpha$ in human alveolar macrophages from patients with pulmonary sarcoidosis and fribrosis. Immunbiology 175: 100 (1987).

41 Spatafora, M.; Merendino, A.; Chiappara, G.; Gjomarkaj, M.; Melis, M.; Bellia, V.; Bonsignore, G.: Lung compartmentalization of increased TNF releasing ability by monoculear phagocytes in pulmonary sarcoidosis. Chest 96: 542-549 (1989).

42 Wewers, M.D.; Saltini, C.; Sellers, S.; Tocci, M.J.; Bayne, E.K.; Schmidt, J.A.; Crystal, R.G.: Evaluation of alveolar macrophages in normals and individuals with active pulmonary sarcoidosis for the spontaneous expression of interleukin-1 $\beta$ gene. Cell. Immunol. 107: 479-488 (1987).

43 Kunkel, S.L.; Spengler, M.; May, M.A.; Spengler, R.; Larrick, J.; Remick, D.: Prostaglandin $\mathrm{E}_{2}$ regulates macrophage-derived tumor necrosis factor gene expression. J. Biol. Chem. 263: 5380-5384 (1988).

44 Molvig, J.; Baek, L.; Christensen, P.; Manogue, K.R.; Vlassara, H.; Platz, P.; Nielsen, L.S.; Svejgaard, A.; Nerup, J.: Endotoxin-stimulated human monocyte secretion of interleukin-1, tumor necrosis factor alpha and prostaglandin $E_{2}$ shows stable interindividual differences. Scand. J. Immunol. 27: 705-716 (1988).

45 Rhodes, J.; Ivanyi, J.; Cozens, P.: Antigen presentation by human monocytes: Effects of modifying major histocompatibility complex class II antigen expression and interleukin-1 production by using recombinant interferons and corticosteroids. Eur. J. Immunol. 16: 370-375 (1986).

46 Burchett, S.K.; Waewer, W.M.; Westall, J.A.; Larsen, A.; Kronheim, S.; Wilson, C.B.: Regulation of tumor necrosis factor/ cachectin and IL-1 secretion in human mononuclear phagocytes. J. Immunol. 140: 3473-3481 (1988).

47 Ferrante, A.; Nandoskar, M.; Walz, A.; Goh, D.H.; Kowanko, I.C.: Effects of tumor necrosis factor alpha and interleukin-1 alpha and beta on human neutrophil migration, respiratory burst and degranulation. Int. Archs Allergy appl. Immun. 86: 82-91 (1988).

48 Hensel, G.; Männel, D.N.; Pfizenmaier, K.; Krönke, M.: Autocrine stimulation of TNF-alpha mRNA expression in HL-60 cells. Lymphokine Res. 6: 119-125 (1987).

49 Heidenreich, S.; Weyers, M.; Gong, J.H.; Sprenger, H.; Nain, M.; Gemsa, D.: Potentiation of lymphokine-induced macrophage activation by tumor necrosis factor-alpha. J. Immunol. 140: 1511-1518 (1988).

50 Ming, J.W.; Bersani, L.; Mantovani, A.: Tumor necrosis factor is chemotactic for monocytes and polymorphonuclear leukocytes. J. Immunol. 138: 1469-1474 (1987).

51 Meuer, S.C.; Hussey, R.E.; Cantrell, D.A.; Hodgdon, J.C.; Schlossman, S.F.; Smith, K.A.; Reinherz, E.L.: Triggering of the $\mathrm{T} 3-\mathrm{Ti}$ antigen-receptor complex results in clonal $\mathrm{T}$-cell 
proliferation through an interleukin-2-dependent autocrine pathway. Proc. natn. Acad. Sci. USA 81: 1509-1513 (1984).

52 Bitterman, P.B.; Saltzman, L.E.; Adelberg, S.; Ferrans, V.J.; Crystal, R.G.: Alveolar macrophage replication, one mechanism for the expansion of the mononuclear phagocyte population in the chronically inflamed lung. J. Clin. Invest. 74: 460-469 (1984).

53 Nedwin, G.L.; Svedersky, L.P.; Bringman, T.S.; Palladino, M.A.; Goeddel, D.V.: Effect of interleukin-2 interferon-gamma, and mitogens on the production of tumor necrosis factors a, ß. J. Immunol. 135: 2492-2497 (1985).

54 Snyder, D.S.; Unanue, E.R.: Corticosteroids inhibit murine macrophage Ia expression and interleukin-1 production. J. Immunol. 129: 1803-1805 (1982).
55 Beutler, B.; Cerami, A.: Cachectin: more than a tumor necrosis factor. N. Engl. J. Med. 316: 379-385 (1987).

Received: March 1, 1991

Accepted after revision: May 8, 1991

Correspondence to: Dr. J. Müller-Quernheim

Third Department of Internal Medicine

Division of Pulmonology

Johannes Gutenberg University

Langenbeckstr. 1

D-W-6500 Mainz (FRG) 